\title{
Dimethyl ether as Zero Emission Fuel-Synergies with Biogas and Biomass Plants
}

\author{
Johann Gruber Schmidt* \\ Technical University Vienna, Austria \\ Received: 鰏June 15, 2018; Published: 䟧July 03, 2018 \\ *Corresponding author: Johann Gruber Schmidt, Technical University Vienna, Austria
}

\section{Introduction}

In Iceland a methanol plant named in honour of the noble prize laureate [1] operating since 2011. As substrate they use carbon dioxide and hydrogen producing methanol. Methanol is the simplest alcohol and well know since the developments of Paul Sabatier and the catalysis processes [2], in liquid phase at environment pressure and temperature, and is a synthetic alcohol. In the Georg Olah Plant [3] carbon dioxide and hydrogen are mixed $1 \mathrm{~mol}: 3 \mathrm{~mol}$ together to form a syngas, being compressed and transformed under the help of catalysts to methanol (methanol synthesis).

$$
\mathrm{CO}_{2}+3 \mathrm{H}_{2} \mathrm{CH}_{3} \mathrm{OH}+\mathrm{H}_{2} \mathrm{OQ}(-45 \mathrm{~kJ} / \mathrm{mol})
$$

In most processes the methanol synthesis is running at a pressure range 30 bar up to $100 \mathrm{bar}$ and a temperature range $200{ }^{\circ} \mathrm{C}$ up to $400{ }^{\circ} \mathrm{C}$. The conversion rate is given in the range of $25 \%$ up to $35 \%$ and therefor recycling of the unconverted gas in the methanol reactor back, to increase the conversion rate of synthetic gas and production rate. Leaving the methanol reactor, the product gas will be cooled down andthe condensate mixture of water and methanol is distilled and separated into water and product methanol. The methanol synthesis with carbon dioxide hydrogen is needed, generated by wet electrolysis.

$$
2 \mathrm{H}_{2}+\mathrm{O}_{2}+Q(490 \mathrm{~kJ} / \mathrm{mol})
$$

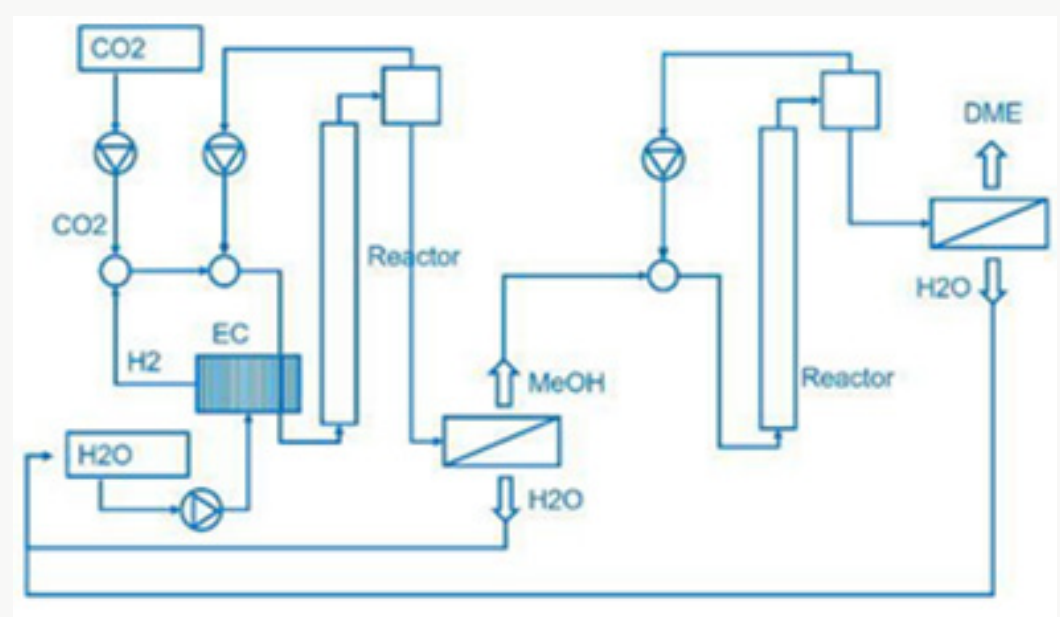

Figure 1: Methanol and Dimethyl ether from carbon dioxide and water.

From water and the electric power needed for the electrolysis is generated by geothermal heat conversion to electricity (Figure 1). This is a special property of Iceland. Now the question arises, where does the carbon dioxide come from? In the most common case. Carbon dioxide is separated from exhaust gas from fossil fuelled power plants and industrial processes. Using fossil carbon dioxide in plant process the George Olah plant [3] is now accelerating the consumption of fossil fuels if we use methanol as a fuel. Therefor methanol should be used in chemical industry fixing carbon dioxide [1]. But if we use methanol as fuel in transportation, the combustion of methanol leads to carbon dioxide and water being transferred to normally carbon dioxide transferred to the 
environment is a dilution of carbon dioxide in the air. We watch that methanol burned in a classical Otto motor cycle additional produces compared to fossil diesel fuel in a diesel engine higher pollution, dust, soot and a higher amount of carbon dioxide in the exhaust gas. Therefor methanol is converted to dimethyl ether by extraction of water under acid conditions $[4,5]$.

$$
2 \mathrm{CH}_{3} \mathrm{OHCH}_{3} \mathrm{OCH}_{3}+\mathrm{H}_{2} \mathrm{O}+\mathrm{Q}(-18 \mathrm{~kJ} / \mathrm{mol})
$$

Dimethyl ether is often mentioned as the ideal Diesel fuel [8], tested over long years from VOLVO [6] and by MACK TRUCK [7] in heavy trucks on the road. Dimethyl ether is the simplest ether a synthetic fuel, certificated by the ISO 16 681:2013 by the IDA, produced from methanol or by direct synthesis (Figure 2).

$$
3 \mathrm{CO}+3 \mathrm{H}_{2} \mathrm{CH}_{3} \mathrm{OCH}_{3}+\mathrm{CO}_{2} \mathrm{Q}(\mathrm{kJ} / \mathrm{mol})
$$

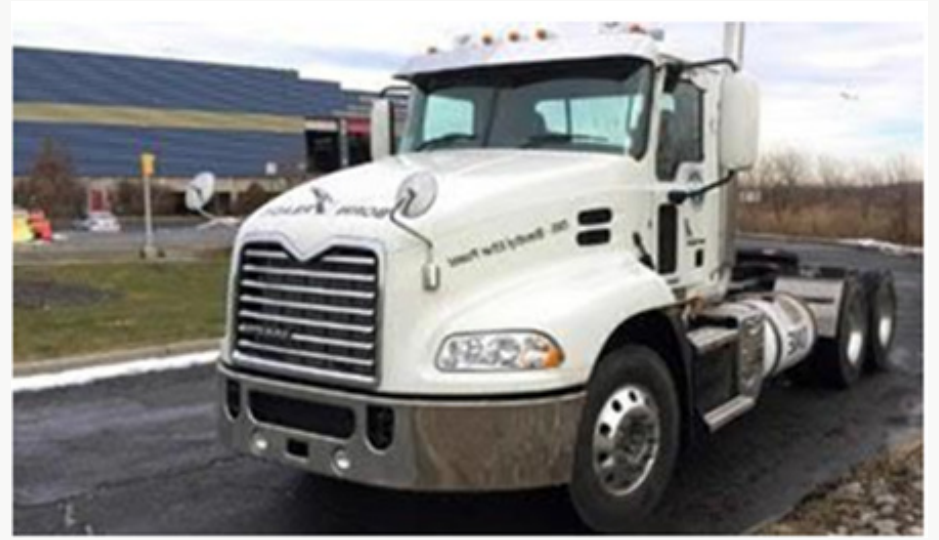

Figure 2: Mack truck testing Dimethyl ether.

In most cases there is no application of methanol in transport, civil, agriculture and forestry, because they are running on fossil diesel. Heavy strong robust power machines are needed and the diesel engine is the ideal power machine. Methanol cannot substitute fossil diesel directly. But dimethyl ether has this needed property. As shown from MACK TRUCK (New York) [7] testing
Dimethyl ether in heavy trucks [7]. Since VOLVO (Sweden) [6] started in using Dimethyl ether in heavy trucks in 2008, running over five years the trucks on the road (Figure 3), and moved then to the USA at MACK TRUCK [7], it is well known that dimethyl ether is a story of success and dimethyl ether is the ideal Diesel fuel $[6,7]$.

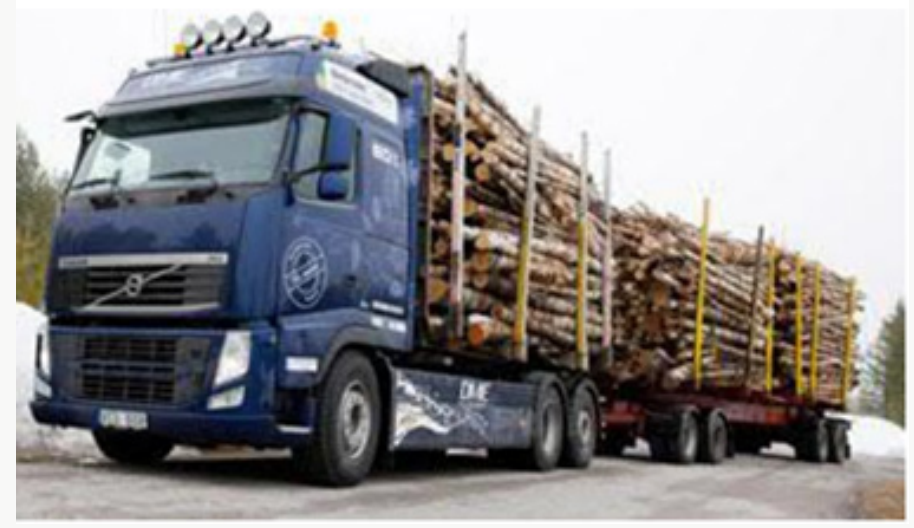

Figure 3: VOLVO heavy truck running on Dimethyl ether.

\section{Ethanol, Biodiesel}

Using corn from agriculture bioethanol is produced with fermentation. Corn is a food product not agricultural waste. Bioethanol has the same combustion and emission problem as methanol: it can only be used in a gasoline engine and leads to higher pollution, lower efficiency, soot dust, and high carbon dioxide than dimethyl ether. In Europe biodiesel is mixed with fossil diesel. Biodiesel is produced from oil and fatties over catalytic esterification, but again biodiesel has the same combustion problem as methanol: although biodiesel can be used in diesel engines, biodiesel leads to higher pollution, lower efficiency, soot dust, and high carbon dioxide than dimethyl ether [6].

\section{Biogas}

The anaerobic fermentation process enables to produce biogas, consisting of methane and carbon dioxide $\left(\mathrm{CH}_{4}, \mathrm{CO}_{2}\right)$. Biogas can be 
produced from wet biogenic waste. The anaerobic process can be realized in wet phases or in dry phases but always lead to biogas and digestate, which can be recycled again. In most application biogas is used to generate electricity and heat. The electric efficiency of biogas engines is $30 \%$ up to $36 \%$, and we have an exhaust gas, therefore no zero emission.

\section{Forestry biomass}

In Forestry wood is used for pulp and paper and for wood in civil and industry. Generating heat from wood chips with a warm water boiler is well known. In the most application biomass is used to generate heat. The thermal efficiency is low $75 \%$ up to $85 \%$, and we have an exhaust gas and again no zero emission.

\section{Reforming and gasification for dimethyl ether}

Dimethyl ether can be produced from biogas and biomass.
Biomass as waste biogenic mass can be used for gasification to generate synthetic gas and char coal. The char coal is carbon, the synthetic gas consists of $\mathrm{CO}: 23 \%, \mathrm{H}_{2}: 20 \%, \mathrm{CH}: 1 \%, 02<0.1 \%$, CxHy: $3 \%$, Rest $\mathrm{CO}_{2}$. The heat caloric value is about $1.5 \mathrm{kWh} / \mathrm{m}^{3}$. Charcoal can be reused again and converted to syngas over the known water gas reaction

$$
\mathrm{C}+\mathrm{H}_{2} \mathrm{O} \mathrm{CO}+\mathrm{H}_{2}+Q(135 \mathrm{~kJ} / \mathrm{mol})
$$

Biogas can be used to generate synthetic gas with dry reforming:

$$
\mathrm{CH}_{4}+\mathrm{CO}_{2} 2 \mathrm{CO}+2 \mathrm{H}_{2}+Q(251 \mathrm{~kJ} / \mathrm{mol})
$$

The synthetic gas consists of $\mathrm{CO}: 40 \%, \mathrm{H}_{2}: 40 \%, \mathrm{CH}: 3 \%, \mathrm{O}_{2}<$ $0.1 \%$, CxHy: $1 \%$, Rest $\mathrm{CO}_{2}$. The heat caloric value is about $2.5 \mathrm{kWh} /$ $\mathrm{m}^{3}$. In both cases syngas can be transformed to dimethyl ether over direct synthesis: $3 \mathrm{CO}+3 \mathrm{H}_{2} \mathrm{CH}_{3} \mathrm{OCH}_{3}+\mathrm{CO}_{2}+\mathrm{Q}(-254 \mathrm{~kJ} / \mathrm{mol})$.

\section{Hydrogen}

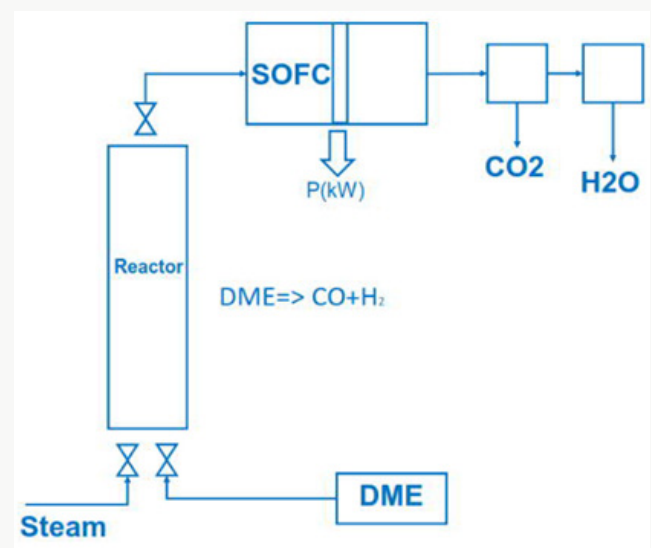

Figure 4: Dimethyl ether and SOFC Cycle.

Cheap hydrogen is the basic requirement for the production of cheap and competitive dimethyl ether from methanol (Figure 4). Hydrogen from electrolysis costs electric power $\sim 5.0 \mathrm{kWh} / \mathrm{m}^{3} \mathrm{H}_{2}$. Hydrogen generated from waste heat, enables to split water into hydrogen and oxygen with metals at temperatures from $400{ }^{\circ} \mathrm{C}$ up to $800^{\circ} \mathrm{C}$ :

$$
\mathrm{Me}+\frac{1}{2} \mathrm{O} 2 \mathrm{MeO}+Q(\mathrm{~kJ} / \mathrm{mol}) ; \mathrm{MeOMe}+\frac{1}{2} \mathrm{O} 2-Q(\mathrm{~kJ} / \mathrm{mol})
$$

SOFC or thermionic and magneto hydrodynamic Generator Using dimethyl ether in a SOFC (solid oxide fuel cell) cell dimethyl ether has to be converted to syngas by steam reforming

$$
\mathrm{CH} 3 \mathrm{OCH} 3+\mathrm{H} 2 \mathrm{O} 2 \mathrm{CO}+4 \mathrm{H} 2+\mathrm{Q}(219 \mathrm{~kJ} / \mathrm{mol})
$$

The exhaust gas from the SOFC cell consists of carbon dioxide and steam.

$$
\begin{aligned}
& \mathrm{CO}+\frac{1}{2} \mathrm{O}_{2} \mathrm{CO}_{2}+Q(-280 \mathrm{~kJ} / \mathrm{mol}) \\
& \mathrm{H}_{2}+\frac{1}{2} \mathrm{O}_{2} \mathrm{H}_{2} \mathrm{O}+Q(-245 \mathrm{~kJ} / \mathrm{mol})
\end{aligned}
$$

SOFC cells operate in a temperature range $800{ }^{\circ} \mathrm{C}$ up to 1000 ${ }^{\circ} \mathrm{C}$, at nearly environment pressure and have an electric efficiency of $50 \%$ up to $60 \%$. Another possibility is to generate heat with combustion of dimethyl ether in a metal oxide reactor.

$$
\mathrm{CH}_{3} \mathrm{OCH}_{3}+3 \mathrm{O}_{2} 2 \mathrm{CO}_{2}+3 \mathrm{H}_{2} \mathrm{O}+\mathrm{Q}(-1310 \mathrm{~kJ} / \mathrm{mol})
$$

The generated heat can be direct converted to electric energy with a thermionic generator. Thermionic generators have an electric efficiency from $25 \%$ up to $35 \%$, combined with magneto hydrodynamic generators having an electric efficiency from $30 \%$ up to $40 \%$, we gain in sum from $55 \%$ up to $75 \%$ for the direct conversion of heat to electric energy (Figure 5). In both applications we oxidize dimethyl ether to carbon dioxide and water under pressure up to 50 bars.

$$
\mathrm{CH}_{3} \mathrm{OCH}_{3}+3 \mathrm{O}_{2} 2 \mathrm{CO}_{2}+3 \mathrm{H}_{2} \mathrm{O}+\mathrm{Q}(-1310 \mathrm{~kJ} / \mathrm{mol})
$$

Do that the exhaust gas consisting of carbon dioxide and steam can be collected as condensate in different tanks. This enables carbon dioxide and water to be reused in such plants like 
the George Olah Plant [3] and Oberon plant [4] again. The step of collecting carbon dioxide and water is the closure of the methanol over the dimethyl ether processes. It is now a closed cycle collecting carbon dioxide in a tank wo be recycled to methanol and dimethyl ether process again. This closed cycle now reduces the emission of greenhouse gas like carbon dioxide and can be seen as a sustainable property of the carbon dioxide recycling. Carbon dioxide now is a substrate and a basic part in the fuel production and not a pollution in the exhaust gas anymore. Under this conditions carbon dioxide and the emission certificates connected to carbon dioxide can be used in a global trade [8].

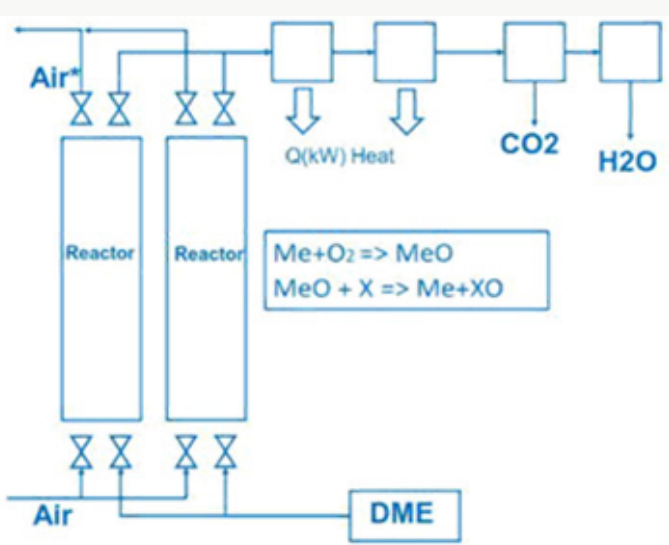

Figure 5: Dimethyl ether and high temperature heat generation.

\section{Closing the cycle}

To reach zero emission we must convert Dimethyl ether into carbon dioxide and water. Carbon dioxide and water can be converted back (recycled) to dimethyl ether with electric energy and heat. Under this cycle we generate only this amount of carbon dioxide, connected with dimethyl ether. Using more dimethyl ether enables to reuse more carbon dioxide and the process is acting like a carbon dioxide sink. Focusing on this property of zero emission enables to save energy and substrate in agriculture and forestry, in civil and transportation (Figure 6). Using waste from agriculture and forestry, using biogenic waste from hotels, food industry and biogenic waste from municipal and civil waste, reduces the pressure on new and fresh biomass, reduces the pressure on fossil substrates. Under the property of zero emission the methanol cycle of the George Olah plant [3] will be renewable and also the dimethyl ether plants of Oberon [4,9].

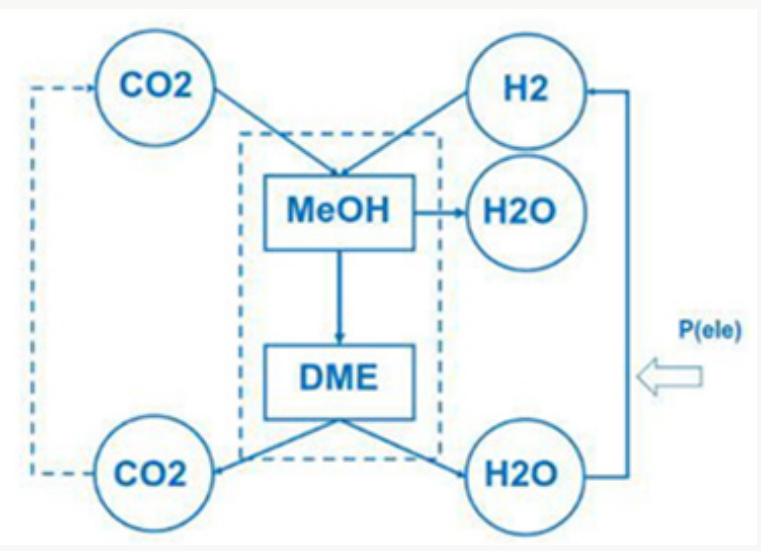

Figure 6: Dimethyl ether closed cycle.

\section{References}

1. G Olah (2006) Beyond oil and gas: the methanol economy, Wiley Publ.

2. P Sabatier (1914) Heterogenous catalysis, Salzwasser Publ.

3. (2012) Carbon Recycling International, the George Olah Plant.

4. (2017) Oberon Inc, The Alternative Fuel Dimethyl ether.

5. Halder Topsoe (2012) Dimethyl ether.
6. (2013) Volvo, Bio DME.

7. (2017) Mack Truck tests alternative fuel DME.

8. (2002) ETS Certificates, EU.

9. (1999) AVL List, Study of modification of diesel engines for dimethyl ether, Graz, Austria. 
(C) Co This work is licensed under Creative

To Submit Your Article Click Here: Submit Article

DOI: 10.32474/CIACR.2018.03.000165

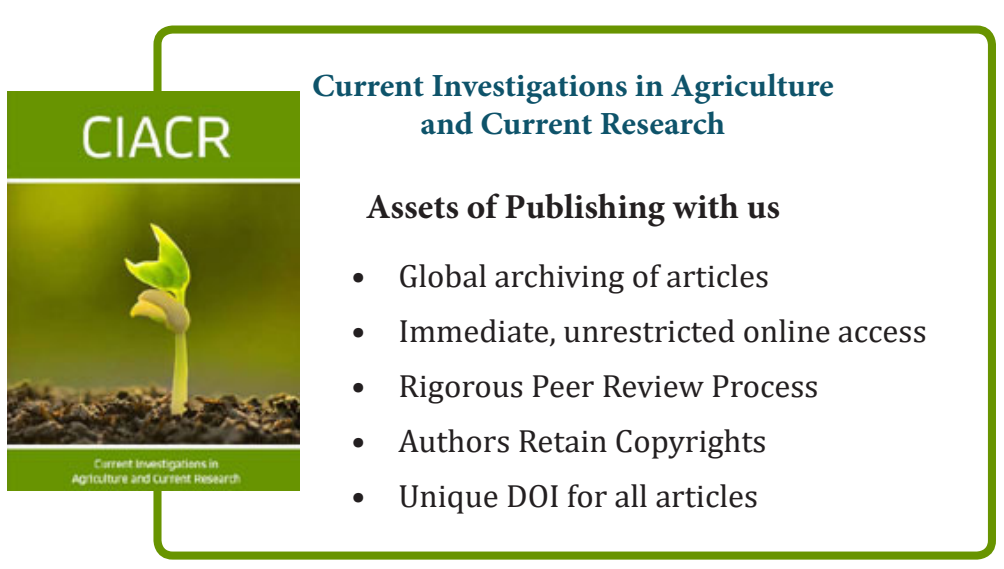

